\title{
Decreased Complications After Total Laryngectomy Using a Clinical Care Pathway
}

\author{
Sabrina A. Brody-Camp, MD, MPH, ${ }^{1}$ Sean M. Parsel, DO, ${ }^{1}$ Zane A. Freeman, DO, ${ }^{1}$ Edward D. McCoul, MD, MPH, ${ }^{2,3}$ \\ Christian Hasney, MD, ${ }^{2}$ Brian A. Moore, MD $^{2,3}$ \\ ${ }^{1}$ Department of Otolaryngology-Head and Neck Surgery, Tulane University School of Medicine, New Orleans, LA ${ }^{2}$ Department of \\ Otorhinolaryngology, Ochsner Clinic Foundation, New Orleans, LA ${ }^{3}$ The University of Queensland Faculty of Medicine, Ochsner Clinical \\ School, New Orleans, LA
}

Background: Complications following total laryngectomy can lead to increased hospital length of stay (LOS) and increased health care costs. Our objective was to determine the efficacy of a clinical care pathway for improving outcomes for patients following total laryngectomy.

Methods: This quality improvement study included all adult patients undergoing total laryngectomy-either primary or salvageat a tertiary referral center between January 2013 and December 2018. The primary outcome was hospital LOS measured in postoperative days. The total and specific postoperative complication frequencies were evaluated, as well as 30-day readmission rates and intensive care unit (ICU) LOS.

Results: Sixty-three patients were included in the study: 29 (46.0\%) patients before the pathway implementation and 34 (54.0\%) patients after pathway implementation. Demographic characteristics between the groups were similar. The prepathway cohort had a higher rate of total complications compared to the postpathway group (relative risk $=0.5 ; 95 \% \mathrm{Cl} 0.3-1.0$ ), although the differences in individual complications were similar. The median LOS of 10 days was the same for the 2 cohorts. The median ICU LOS was 1 day greater in the postpathway cohort, but no difference was seen in rates of ICU readmission in the 2 groups. The 30-day readmission rate also was not significant between the 2 groups.

Conclusion: Implementation of a postoperative order set pathway for patients undergoing laryngectomy is associated with decreased overall complication rates. Use of a clinical care pathway may improve outcomes in patients undergoing total laryngectomy.

Keywords: Clinical pathways, laryngectomy, postoperative care

Address correspondence to Brian A. Moore, MD, Department of Otorhinolaryngology, Ochsner Clinic Foundation, 1514 Jefferson Hwy., New Orleans, LA 70121. Tel: (504) 842-4080. Email: brmoore@ochsner.org

\section{INTRODUCTION}

More than 12,000 cases of laryngeal cancer are diagnosed in the United States annually, leading to almost 3,800 deaths. ${ }^{1}$ Total laryngectomy is the gold standard for locally advanced laryngeal cancer and for patients who have failed primary chemoradiation therapy or conservative laryngeal surgery. Since the 1990s, the number of total laryngectomies performed nationally has declined. ${ }^{2}$ The decrease in total laryngectomies is in part because of a shift in the treatment paradigm toward organ preservation, either through nonsurgical treatment or minimally invasive techniques. ${ }^{3-5}$ In spite of this trend, more than 3,000 total laryngectomies are performed annually in the United States and are predominantly concentrated at high-volume centers. ${ }^{6,7}$

A patient's anatomy after a total laryngectomy is considerably altered. Breathing, communication, and swallowing functions are significantly affected by surgery. As a result, the postoperative care of laryngectomy patients can be chal- lenging and requires a unique skill set from caretakers and health care providers. If the limitations of these patients are not recognized, devastating outcomes may result. In 2014, a sentinel event resulting in a patient death occurred at our institution. Formal review concluded that the event resulted from misunderstanding postoperative laryngectomy patient needs. In response to this incident, a multidisciplinary team convened to develop a method to prevent unintended morbidity or mortality. The solution was the implementation of a postoperative order set pathway, consisting of a set of timereleased orders in the electronic medical record (EMR) that is advanced on a daily basis. The goal of the pathway is to standardize interventions and improve delivery of care. Clinical pathways such as the one used at our institution have been implemented elsewhere for a variety of conditions and have been shown to improve patient outcomes while reducing complications, costs, and length of stay (LOS). ${ }^{8-12}$ 
Beginning in January 2016, our institution implemented a laryngectomy pathway for all patients who underwent total laryngectomy. After 3 years, we sought to review how this clinical pathway affected outcomes in postoperative laryngectomy patients. Our objective was to compare patients who had had total laryngectomies at our institution prior to and after pathway implementation and to evaluate whether this intervention decreased complication rates, readmission rates, and LOS. We hypothesized that the use of the laryngectomy pathway would decrease hospital LOS and improve complication rates. To assess these outcomes, we conducted a quality improvement study of our laryngectomy population.

\section{METHODS}

\section{Study Setting and Population}

We conducted a quality improvement study of retrospective data for patients who underwent total laryngectomy for oncologic indications by 5 head-and-neck surgeons at a tertiary referral center in Southeast Louisiana between January 2013 and December 2018. Patients were eligible for inclusion if they had a total laryngectomy for squamous cell carcinoma involving the larynx. Inclusion criteria were based on current procedural terminology (CPT) codes corresponding to total laryngectomy without radical neck dissection (CPT 31360) and total laryngectomy with radical neck dissection (CPT 31365). Patients were excluded from the study if they were $<18$ years of age or underwent laryngectomy for other than an oncologic etiology.

The population was separated into 2 cohorts depending on the use of the laryngectomy pathway. The pathway was implemented on January 1, 2016, and all patients presenting for laryngectomy after this date received postoperative treatment according to the pathway. Thus, the prepathway cohort included patients receiving total laryngectomy between January 2013 and December 2015, while the postpathway cohort included patients receiving total laryngectomy between January 2016 and December 2018.

\section{Laryngectomy Pathway}

The laryngectomy pathway order set was created to address orders commonly used with all laryngectomy patients. Once admitted after a laryngectomy, patients are automatically enrolled. The pathway is a time-dependent order set that is electronically released on subsequent postoperative days depending on patient progression and consists of standard orders on postoperative days 0 through 7 (Figure, Table 1). The patient's nurse allows release of each day's order set manually. This order set includes labs, imaging, early consultation for social work for home durable medical equipment, physical therapy and occupational therapy, and speech and language pathology. Nursing communication orders include placing a sign above the patient's bed that reads "obligate neck breather" and a wristband that reads the same. Also included is an impaired communication protocol that requires a staff member to physically present to the patient's room whenever the call button is pressed. Orders such as tube feeding formula require manual entry depending on the patient and nutrition needs.

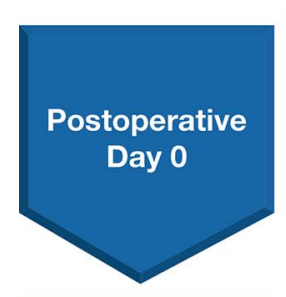

- X-rays (chest, abdomen)

- Labs (CBC, CMP, PTH)

- NPO

- Speech therapy consult

- PT/OT

- Impaired communication protocol

- Obligate neck breather sign above bed

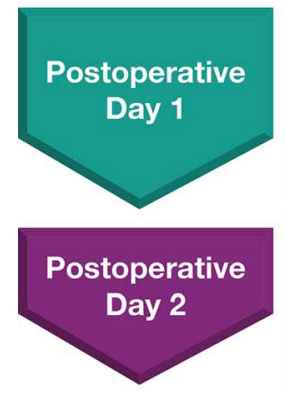

- Chest x-ray

- Labs

- NPO

- Nutrition consult

- Out of bed to chair

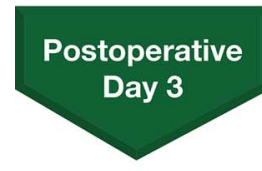

- Out of bed $3 x$ daily

- Start continuous tube feeds @ 10 mL/h

- Lary tube in stoma

- Home health order for lary supplies

- Advance tube feed to goal

- All medications via PEG tube

- Educate patient on stoma, PEG, and wound care

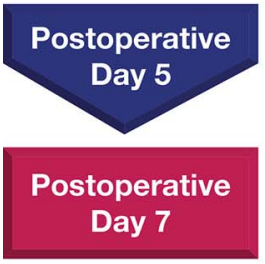

- Ambulate $3 x$ daily

- HME and lary tube worn at all times

- Discharge planning started

- Caregiver in room overnight

- Staples/sutures removed

- Discharge instructions

Figure. Flow diagram of laryngectomy clinical pathway. CBC, complete blood count; CMP, comprehensive metabolic panel; $\mathrm{HME}$, heat moisture exchange; lary tube, laryngectomy tube; NPO, nothing by mouth; PEG, percutaneous gastrostomy; PT/OT, physical therapy/occupational therapy; PTH, parathyroid hormone.

\section{Data Sources and Measurements}

Patient information was obtained from manual review of the EMRs at the Ochsner Clinic Foundation by 3 investigators (S.B.C, S.M.P., and Z.A.F.) for all patients meeting inclusion criteria. Specific data were extracted for patient demographics (age, sex, and race), medical history, perioperative details, and postoperative care. Specific medical history included prior chemotherapy or radiation therapy and medical comorbidities. The Charlson Comorbidity Index (CCl) and the National Surgical Quality Improvement Program (NSQIP) surgical risk were calculated for each patient. ${ }^{13,14}$ The perioperative data included total operative time and whether or not free tissue transfer was used for reconstruction. Postoperative outcome measures included intensive care unit (ICU) LOS, total hospital LOS, ICU readmissions, 30-day readmission rates, and postoperative complications. Postoperative complications included development of a wound complication (including pharyngocutaneous fistula formation) or hematoma, operative reexploration or intervention, cardiovascular complications, sepsis, and death. 
Table 1. Detailed Laryngectomy Pathway Orders

\begin{tabular}{|c|c|c|c|c|c|c|c|c|}
\hline $\begin{array}{c}\text { Intervention } \\
\text { Type }\end{array}$ & $\begin{array}{l}\text { Postoperative } \\
\text { Day } 0\end{array}$ & $\begin{array}{c}\text { Postoperative } \\
\text { Day } 1\end{array}$ & $\begin{array}{l}\text { Postoperative } \\
\text { Day } 2\end{array}$ & $\begin{array}{l}\text { Postoperative } \\
\text { Day } 3\end{array}$ & $\begin{array}{c}\text { Postoperative } \\
\text { Day } 4\end{array}$ & $\begin{array}{l}\text { Postoperative } \\
\text { Day } 5\end{array}$ & $\begin{array}{l}\text { Postoperative } \\
\text { Day } 6\end{array}$ & $\begin{array}{c}\text { Postoperative } \\
\text { Day } 7\end{array}$ \\
\hline Outcomes & $\begin{array}{l}\text { Mechanical vent } \\
\text { weaned in OR }\end{array}$ & $\begin{array}{l}\text { Out of bed to chair } \\
\text { once }\end{array}$ & $\begin{array}{l}\text { Out of bed } 3 \times \\
\text { Lary tube worn at } \\
\text { all times (if } \\
\text { applicable) }\end{array}$ & $\begin{array}{l}\text { Out of bed } 3 \times \\
\text { HME and lary tube } \\
\text { worn at all times }\end{array}$ & $\begin{array}{l}\text { Out of bed } 3 \times \\
\text { Ambulate } 3 \times \\
\text { HME and lary tube } \\
\text { worn at all times }\end{array}$ & $\begin{array}{l}\text { Ambulate } 3 \times \\
\text { HME and lary } \\
\text { tube worn at } \\
\text { all times } \\
\text { Discharge } \\
\text { planning }\end{array}$ & $\begin{array}{l}\text { Ambulate } 3 \times \\
\text { HME removal } \\
\text { and } \\
\text { replacement } \\
\text { Stoma } \\
\quad \text { suctioning } \\
\text { Stoma care }\end{array}$ & $\begin{array}{l}\text { Caregiver in room } \\
\text { with patient } \\
\text { overnight and } \\
\text { provides care } \\
\text { Patient and family } \\
\text { demonstrate that } \\
\text { patient can safely } \\
\text { go home } \\
\text { Patient and family } \\
\text { verbalize } \\
\text { understanding of } \\
\text { discharge/ } \\
\text { medication } \\
\text { instructions }\end{array}$ \\
\hline Diagnostics & $\begin{array}{l}\text { Chest and abdominal } \\
\quad x \text {-rays } \\
\text { CBC } \\
\text { CMP } \\
\text { PTH } \\
\text { Prealbumin } \\
\text { lonized calcium }\end{array}$ & $\begin{array}{l}\text { Chest x-ray } \\
\text { CBC } \\
\text { CMP } \\
\text { PTH } \\
\text { lonized calcium }\end{array}$ & & & & $\mathrm{CBC}$ & & \\
\hline Treatments & $\begin{array}{l}\text { SLP evaluation and } \\
\text { treatment } \\
\text { PT/OT evaluation and } \\
\text { treatment } \\
\text { No ties around neck (if } \\
\text { flap) } \\
\text { Keep head in neutral } \\
\text { position (if flap) } \\
\text { Flap checks every } \\
\text { hour } \\
\text { Tracheostomy tube in } \\
\text { stoma } \\
\text { Stoma care by RT } \\
\text { Strip bulb suction and } \\
\text { record } \\
\text { Neurovascular checks } \\
\text { on donor site }\end{array}$ & $\begin{array}{l}\text { Humidified air via } \\
\text { tracheostomy } \\
\text { collar } \\
\text { Clean incisions } \\
\text { with saline and } \\
\text { apply bacitracin } \\
\text { Inpatient consult } \\
\text { to hematol- } \\
\text { ogy/oncology } \\
\text { psychology } \\
\text { Continue impaired } \\
\text { communication } \\
\text { protocol }\end{array}$ & $\begin{array}{l}\text { Place HME and } \\
\text { change daily } \\
\text { Flap checks every } 2 \\
\text { hours } \\
\text { All medications per } \\
\text { tube } \\
\text { Discontinue } \\
\text { arterial line }\end{array}$ & $\begin{array}{l}\text { Place HME and } \\
\text { change daily } \\
\text { All medications per } \\
\text { PEG tube }\end{array}$ & & $\begin{array}{l}\text { OK for ties } \\
\text { No ties around } \\
\text { neck sign } \\
\text { may be taken } \\
\text { down } \\
\text { Flap checks } \\
\text { every } 4 \text { hours } \\
\text { Neurovascular } \\
\text { checks on } \\
\text { donor site } \\
\text { every shift } \\
\text { Tegaderm off } \\
\text { STSG donor } \\
\text { site }\end{array}$ & & $\begin{array}{l}\text { Start rooming in } \\
\text { Staples/sutures } \\
\text { removed prior to } \\
\text { discharge if patient } \\
\text { not previously } \\
\text { radiated }\end{array}$ \\
\hline
\end{tabular}


Table 1. Cont.

\begin{tabular}{|c|c|c|c|c|c|c|c|c|}
\hline $\begin{array}{l}\text { Intervention } \\
\text { Type }\end{array}$ & $\begin{array}{c}\text { Postoperative } \\
\text { Day } 0\end{array}$ & $\begin{array}{c}\text { Postoperative } \\
\text { Day } 1\end{array}$ & $\begin{array}{l}\text { Postoperative } \\
\text { Day } 2\end{array}$ & $\begin{array}{l}\text { Postoperative } \\
\text { Day } 3\end{array}$ & $\begin{array}{c}\text { Postoperative } \\
\text { Day } 4\end{array}$ & $\begin{array}{c}\text { Postoperative } \\
\text { Day } 5\end{array}$ & $\begin{array}{c}\text { Postoperative } \\
\text { Day } 6\end{array}$ & $\begin{array}{c}\text { Postoperative } \\
\text { Day } 7\end{array}$ \\
\hline Medications & $\begin{array}{l}\text { Duo nebs q4h } \\
\text { Morphine or Dilaudid } \\
\text { PRN } \\
\text { Unasyn or } \\
\quad \text { clindamycin and } \\
\text { ciprofloxacin } \\
\text { Famotidine } \\
\text { Synthroid } \\
\text { Ondansetron } \\
\text { Metoclopramide PRN } \\
\text { Promethazine PRN } \\
\text { IVF infusion }\end{array}$ & $\begin{array}{l}\text { Bacitracin } \\
\text { ointment } \\
\text { PCA if needed } \\
\text { Melatonin or } \\
\text { zolpidem }\end{array}$ & & Hycet via tube & Stop antibiotics & & & \\
\hline
\end{tabular}


Table 1. Cont.

\begin{tabular}{|c|c|c|c|c|c|c|c|c|}
\hline $\begin{array}{c}\text { Intervention } \\
\text { Type }\end{array}$ & $\begin{array}{c}\text { Postoperative } \\
\text { Day } 0\end{array}$ & $\begin{array}{c}\text { Postoperative } \\
\text { Day } 1\end{array}$ & $\begin{array}{c}\text { Postoperative } \\
\text { Day } 2\end{array}$ & $\begin{array}{c}\text { Postoperative } \\
\text { Day } 3\end{array}$ & $\begin{array}{c}\text { Postoperative } \\
\text { Day } 4\end{array}$ & $\begin{array}{c}\text { Postoperative } \\
\text { Day } 5\end{array}$ & $\begin{array}{c}\text { Postoperative } \\
\text { Day } 6\end{array}$ & $\begin{array}{c}\text { Postoperative } \\
\text { Day } 7\end{array}$ \\
\hline Activity & $\begin{array}{l}\text { Bed rest } \\
\text { Head of bed elevated }\end{array}$ & $\begin{array}{l}\text { Progressive } \\
\text { mobility } \\
\text { protocol }\end{array}$ & & & & & & \\
\hline Diet/Nutrition & Diet NPO & $\begin{array}{l}\text { Inpatient consult } \\
\text { to dietitian/ } \\
\text { nutritionist } \\
\text { Daily recorded } \\
\text { weight }\end{array}$ & $\begin{array}{l}\text { Start continuous } \\
\text { TF at } 10 \mathrm{~mL} / \mathrm{h} \text { for } \\
24 \text { hours } \\
\text { Decrease IVF to } \\
\text { keep constant } \\
\text { total intake }\end{array}$ & $\begin{array}{l}\text { Increase TF to } \\
\text { target }\end{array}$ & & & & \\
\hline Prophylaxis & $\begin{array}{l}\text { TED hose } \\
\text { SCD } \\
\text { Heparin or Lovenox }\end{array}$ & & & & & & & \\
\hline Education & & & $\begin{array}{l}\text { Laryngectomy } \\
\text { training }\end{array}$ & $\begin{array}{l}\text { Stoma care } \\
\text { HME } \\
\text { PEG care } \\
\text { Wound care }\end{array}$ & $\begin{array}{c}\text { Continue stoma, } \\
\text { HME, PEG, and } \\
\text { wound care }\end{array}$ & $\begin{array}{l}\text { Twice daily: } \\
\text { placing and } \\
\text { removing } \\
\text { HME, stoma } \\
\text { suctioning, } \\
\text { stoma care }\end{array}$ & & \\
\hline
\end{tabular}

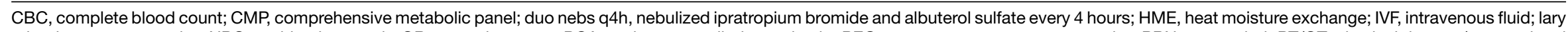

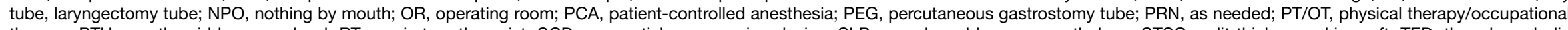

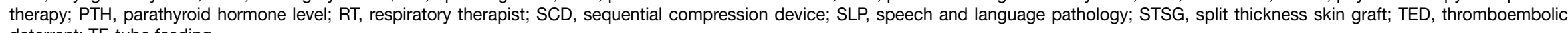
deterrent; TF, tube feeding. 
Brody-Camp, SA

Table 2. Baseline Demographics Overall and by Cohort

\begin{tabular}{|c|c|c|c|c|}
\hline Variable & $\begin{array}{c}\text { All Patients, } \\
n=63\end{array}$ & $\begin{array}{l}\text { Prepathway Cohort, } \\
\qquad n=29\end{array}$ & $\begin{array}{l}\text { Postpathway Cohort, } \\
\qquad n=34\end{array}$ & $P$ Value \\
\hline Age, years, median (IQR) & $65.0(59.0-73.0)$ & $66.0(61.0-74.0)$ & $64.0(59.0-71.0)$ & 0.265 \\
\hline Sex & & & & 0.533 \\
\hline Male & $52(82.5)$ & $23(79.3)$ & $29(85.3)$ & \\
\hline Female & $11(17.5)$ & $6(20.7)$ & $5(14.7)$ & \\
\hline Race & & & & 0.130 \\
\hline White & $44(69.8)$ & $23(79.3)$ & $21(61.8)$ & \\
\hline Black & $19(30.2)$ & $6(20.7)$ & $13(38.2)$ & \\
\hline Smoking history & & & & 0.836 \\
\hline Never smoker & $3(4.8)$ & $1(3.4)$ & $2(5.9)$ & \\
\hline Former smoker & $37(58.7)$ & $18(62.1)$ & 19 (55.9) & \\
\hline Current smoker & $23(36.5)$ & $10(34.5)$ & $13(38.2)$ & \\
\hline Alcohol history ${ }^{a}$ & & & & 0.067 \\
\hline Never drinker & $40(66.7)$ & $23(79.3)$ & $17(54.8)$ & \\
\hline Former drinker & $6(10.0)$ & $3(10.3)$ & $3(9.7)$ & \\
\hline Current drinker & $14(23.3)$ & $3(10.3)$ & $11(35.5)$ & \\
\hline Prior radiation therapy & $31(49.2)$ & $15(51.7)$ & $16(47.1)$ & 0.712 \\
\hline Prior chemotherapy & $17(27.0)$ & $8(27.6)$ & $9(26.5)$ & 0.921 \\
\hline Charlson Comorbidity Index, ${ }^{\mathrm{b}}$ median (IQR) & $8.0(8.0-10.0)$ & $8.0(8.0-9.0)$ & $8.5(7.0-10.0)$ & 0.726 \\
\hline NSQIP surgical risk, ${ }^{c}$ median (IQR) & $29.7(27.6-32.6)$ & $28.8(26.0-33.4)$ & $30.3(28.6-32.5)$ & 0.241 \\
\hline \multicolumn{5}{|l|}{ Operative variables } \\
\hline Free tissue transfer & $24(38.1)$ & $6(20.7)$ & $18(52.9)$ & 0.018 \\
\hline Operative duration, min, median (IQR) & $435.0(375.0-630.0)$ & $390.0(330.0-495.0)$ & $495.0(390.0-670.0)$ & 0.053 \\
\hline
\end{tabular}

\section{Outcomes and Analysis}

The primary outcome was defined as hospital LOS measured as a continuous variable in days. Secondary outcomes were clinical complications, ICU LOS, ICU readmissions, and 30-day readmissions. To quantify the difference in prevalence between the prepathway and postpathway groups, we report risk ratios (RR) and $95 \%$ Cls for categorical outcomes. Effect sizes and $95 \% \mathrm{Cls}$ were calculated using biascorrected Hedges $g$ statistic for all continuous variables. For binary comparison of hospital LOS, we established 12 days as the expected LOS for total laryngectomy procedures. This expected value is based on an absolute minimum stay of 7 days, with an additional 5 days to account for securing the patient's social work needs. The effect on LOS was compared to use of the pathway, use of free tissue transfer, prior treatment history (chemotherapy or radiation therapy), $\mathrm{CCI}$, and the NSQIP risk score.

All patients had complete datasets and were not excluded from the analysis. SAS statistical software, version 9.4 (SAS Institute Inc) was used to conduct all analyses.
This quality improvement study involving protected patient information was approved by the Ochsner Clinic Foundation Institutional Review Board (IRB \#2018.240) prior to data collection. The SQUIRE (Standards for QUality Improvement Reporting Excellence) reporting recommendations for quality improvement studies were used to ensure adequate reporting of findings. ${ }^{15}$

\section{RESULTS}

A total of 63 patients met inclusion criteria for the study, and all had follow-up data for analysis. The majority of the patients were white (69.8\%) and male (82.5\%), and the median age at time of surgery was 65.0 years (interquartile range [IQR] 59.0-73.0 years).

Twenty-nine $(46.0 \%)$ patients were in the prepathway cohort, and 34 (54.0\%) patients were in the postpathway cohort. Patients in the 2 groups were similar with respect to patient demographics, use of alcohol or tobacco, and prior chemotherapy or radiation therapy. The postpathway cohort had an increased percentage of free tissue transfer 
Table 3. Postoperative Outcomes by Cohort

\begin{tabular}{|c|c|c|c|c|}
\hline Postoperative Outcome & $\begin{array}{l}\text { Prepathway Cohort, } \\
\qquad n=29\end{array}$ & $\begin{array}{l}\text { Postpathway Cohort, } \\
\qquad n=34\end{array}$ & Risk Ratio (95\% Cl) & $P$ Value \\
\hline Hospital LOS, days, median (IQR) & $10(9-16)$ & $10(8-19)$ & & 0.647 \\
\hline ICU LOS, days, median (IQR) & $2(1-3)$ & $3(2-4)$ & & $<0.001$ \\
\hline ICU readmission & $6(20.7)$ & $2(5.9)$ & $0.4(0.1-1.5)$ & 0.079 \\
\hline 30-day readmission & $3(10.3)$ & $7(20.6)$ & $1.4(0.9-2.2)$ & 0.488 \\
\hline \multicolumn{5}{|l|}{ Postoperative complications } \\
\hline Wound complication & $9(31.0)$ & $4(11.8)$ & $0.5(0.2-1.2)$ & 0.060 \\
\hline Operating room reexploration & $5(17.2)$ & $5(14.7)$ & $0.9(0.3-2.7)$ & 0.784 \\
\hline Hematoma & $1(3.4)$ & $1(2.9)$ & $0.9(0.2-3.8)$ & 0.909 \\
\hline Cardiovascular complication & $5(17.2)$ & $1(2.9)$ & $0.2(0.0-1.4)$ & 0.054 \\
\hline Sepsis & $2(6.9)$ & $0(0.0)$ & $0.5(0.1-2.5)$ & 0.120 \\
\hline Death & $1(3.4)$ & $0(0.0)$ & $0.4(0.0-4.5)$ & 0.275 \\
\hline Overall postoperative complication rate ${ }^{a}$ & $13(44.8)$ & $7(20.6)$ & $0.5(0.3-1.0)$ & 0.030 \\
\hline
\end{tabular}

${ }^{a}$ Defined by the occurrence of a patient having $>0$ complications.

Note: Data are presented as $n(\%)$ unless otherwise noted.

ICU, intensive care unit; LOS, length of stay.

procedures compared with the prepathway cohort $(52.9 \%$ vs $20.7 \%$ ) (Table 2 ).

Both cohorts had a median hospital LOS of 10 days $(P=0.647)$. The median ICU LOS of 3 days for the postpathway cohort was significantly higher than the 2 days for the prepathway cohort, but the rates of ICU readmission were not different between the groups $(\mathrm{RR}=0.4 ; 95 \% \mathrm{Cl} 0.1-1.5)$.

Because the data for hospital and ICU LOS were skewed, RR could not be calculated, so the hospital LOS was treated as a binary entity with a cutoff of 12 days as the expected LOS. RR $(95 \% \mathrm{Cl})$ for the comparison of hospital LOS $<12$ days and $>12$ days was calculated to be 0.9 (0.51.4). Multivariate analysis controlling for morbidity indices$\mathrm{CCl}$ and NSQIP risk - showed no difference in LOS >12 or $<12$ days.

The 30-day readmission rate was similar between cohorts $(\mathrm{RR}=1.4 ; 95 \% \mathrm{Cl}$ 0.9-2.2). Overall, we found a reduction in the rate of total complications among the postpathway cohort compared with the prepathway group $(R R=0.5 ; 95 \%$ $\mathrm{Cl} 0.3-1.0)$, although the differences in individual complications were similar. Table 3 presents outcomes and complications data.

\section{DISCUSSION}

Our study demonstrates a decreased overall complication rate with the implementation of a postoperative clinical care pathway in a cohort of patients undergoing total laryngectomy. However, we found no difference in hospital LOS or in ICU or 30-day readmission rates.

As rates of laryngectomies performed across the United States have decreased, performance of these procedures has become concentrated at high-volume academic centers. ${ }^{2,6,16}$ These specialized institutions must be equipped to properly care for this unique group of patients through education of the patient, family, and staff and by implementing measures that streamline care while safeguarding against potential complications.
Verma and Mahboubi examined trends in total laryngectomies performed in the state of California between 1996 and 2010, and similar to national trends, found an overall decrease in total laryngectomy procedures performed during this period, along with an increasing proportion performed at tertiary referral centers. ${ }^{16}$ Accompanying this trend, the authors found an increase in the overall complication rate. The authors hypothesized that the higher complication rate could be explained by the greater complexity of total laryngectomies with changing treatment protocols and the increasing number of salvage (postradiated) surgeries. Contrary to the findings of the Verma and Mahboubi study, our data demonstrate a decrease in total complication rates associated with total laryngectomies between January 2016 and December 2018. Our finding perhaps indicates a protective effect of the laryngectomy pathway, safeguarding against potential risks that patients undergoing total laryngectomy face postoperatively.

Clinical pathways have been proven to reduce resource utilization without jeopardizing safety. ${ }^{8-12}$ In 1999, Hanna et al examined how a clinical pathway impacted cost and quality of care for postoperative laryngectomy patients at their institution. ${ }^{11}$ The study showed a $14.4 \%$ reduction in hospital cost associated with pathway implementation, as well as a decrease in readmission rate. Our study, while similar in design to that of Hanna et al, differs in that our postintervention population is more than double the size and includes patients reconstructed with free tissue transfer techniques. While we did not examine cost, we found no significant difference between the groups in terms of readmission rate. Our data provide a contemporary example of the use of a clinical pathway for patients undergoing laryngectomy.

Our results echo the positive findings of other studies examining the effects of clinical pathways on patient outcomes. $^{8-10,12}$ We found a decrease in the total complication rate in the postpathway cohort. Thus, the prepathway group was at increased risk of having a complication overall 
even though individual complication rates did not differ significantly between the 2 cohorts. The pathway did not appear to have an effect on overall hospital LOS, even when controlling for comorbidities using the NSQIP and CCI.

Use of free tissue transfer to reconstruct laryngectomy defects has increased at our institution since December 2015, coinciding with the implementation of the laryngectomy pathway. Free flaps, chiefly from the anterolateral thigh, are used for reconstruction in patients with a history of radiation and for bulky primary disease. Free flaps have been proven to reduce fistula rates, feeding tube dependence, and risk of remote esophageal stricture in patients undergoing total laryngectomy who have failed organ preservation treatment. ${ }^{17}$ Patients who undergo free tissue transfer for defects of the head and neck typically stay in the ICU for an average of 2.4 days, ${ }^{18}$ and those who have free flap reconstruction after total laryngectomy have a longer LOS than those not requiring free tissue transfer. ${ }^{19} \mathrm{~A}$ significantly higher percentage of free flaps was used for reconstruction in our postpathway group. This bias in our study could help to explain the increased ICU LOS in the postpathway group and could have mitigated the decrease in overall hospital LOS. In other words, we could have expected a significant increase in LOS given the use of more free flaps; however, perhaps the pathway helped prevent such an increase.

This study has several limitations. Primarily, the retrospective design predisposes our results to reporting bias based on the accuracy of diagnosis classification in the EMR. Reporting bias may lead to inaccurate representation of complications, as they may have been inappropriately recorded. The outcome of LOS is less likely to be affected by reporting bias, although multiple confounding variables may alter the LOS, including patient comorbidities, prior radiation therapy or chemotherapy, and nutrition status. To control for confounding variables, we performed multivariate analyses based on patient comorbidities and surgical risk and found no difference between groups in reference to overall hospital LOS. For the binary comparison of hospital LOS between the groups, we chose the number 12 arbitrarily, although we felt that 12 days was a reasonable expected LOS given an absolute minimum of 7 days and 5 days to accommodate social factors. Further, selection bias may arise as the 2 cohorts are from different time periods. Surgeon expertise likely improves over time, which would affect the total complication rate in the postpathway group. Further follow-up of postpathway cohorts is necessary to confirm the trends found in this study.

\section{CONCLUSION}

The implementation of a postoperative order set pathway for patients undergoing total laryngectomy was associated with a decrease in the overall complication rate at our institution. In an era of declining use of total laryngectomy and higher concentration of total laryngectomies performed at high-volume academic centers, measures that standardize care and improve outcomes should be implemented when possible.

\section{ACKNOWLEDGMENTS}

The authors have no financial or proprietary interest in the subject matter of this article.

\section{REFERENCES}

1. Key statistics for laryngeal and hypopharyngeal cancers. American Cancer Society. Updated January 12, 2021. Accessed February 3, 2021. https://www.cancer.org/cancer/laryngealand-hypopharyngeal-cancer/about/key-statistics.html

2. Orosco RK, Weisman RA, Chang DC, Brumund KT. Total laryngectomy: national and regional case volume trends 1998-2008. Otolaryngl Head Neck Surg. 2013;148(2):243-248. doi: $10.1177 / 0194599812466645$

3. Wolf GT, Fisher SG, Hong WK, et al.; Department of Veterans Affairs Laryngeal Cancer Study Group. Induction chemotherapy plus radiation compared with surgery plus radiation in patients with advanced laryngeal cancer. $N$ Engl J Med. 1991;324(24):1685-1690. doi: 10.1056/NEJM199106133242402

4. Forastiere AA, Goepfert H, Maor M, et al. Concurrent chemotherapy and radiotherapy for organ preservation in advanced laryngeal cancer. $N$ Engl J Med. 2003;349(22):2091-2098. doi: 10.1056/NEJMoa031317

5. Hoffman HT, Porter K, Karnell LH, et al. Laryngeal cancer in the United States: changes in demographics, patterns of care, and survival. Laryngoscope. 2006;116(9 Pt 2 Suppl 111):1-13. doi: 10.1097/01.mlg.0000236095.97947.26

6. Gourin CG, Frick KD. National trends in laryngeal cancer surgery and the effect of surgeon and hospital volume on short-term outcomes and cost of care. Laryngoscope. 2012;122(1):88-94. doi: 10.1002/lary.22409

7. Maddox PT, Davies L. Trends in total laryngectomy in the era of organ preservation: a population-based study. Otolaryngl Head Neck Surg. 2012;147(1):85-90. doi: 10.1177/0194599812438170

8. Rotter T, Kinsman L, James E, et al. Clinical pathways: effects on professional practice, patient outcomes, length of stay and hospital costs. Cochrane Database Syst Rev. 2010;(3):CD006632. doi: 10.1002/14651858.CD006632.pub2

9. Gendron KM, Lai SY, Weinstein GS, et al. Clinical care pathway for head and neck cancer: a valuable tool for decreasing resource utilization. Arch Otolaryngol Head Neck Surg. 2002;128(3):258-262. doi: 10.1001/archotol.128.3.258

10. Husbands JM, Weber RS, Karpati RL, et al. Clinical care pathways: decreasing resource utilization in head and neck surgical patients. Otolaryngl Head Neck Surg. 1999;121(6):755-759. doi: 10.1053/hn.1999.v121.a98217

11. Hanna E, Schultz S, Doctor D, Vural E, Stern S, Suen J. Development and implementation of a clinical pathway for patients undergoing total laryngectomy: impact on cost and quality of care. Arch Otolaryngol Head Neck Surg. 1999;125(11):1247-1251. doi: 10.1001/archotol.125.11.1247

12. Moreno MA, Bonilla-Velez J. Clinical pathway for abbreviated postoperative hospital stay in free tissue transfer to the head and neck: impact in resource utilization and surgical outcomes. Head Neck. 2019;41(4):982-992. doi: 10.1002/hed.25525

13. Bilimoria KY, Liu Y, Paruch JL, et al. Development and evaluation of the universal ACS NSQIP surgical risk calculator: a decision aid and informed consent tool for patients and surgeons. J Am Coll Surg. 2013;217(5):833-842.e1-3. doi: 10.1016/j.jamcollsurg.2013.07.385

14. Charlson M, Szatrowski TP, Peterson J, Gold J. Validation of a combined comorbidity index. J Clin Epidemiol. 1994;47(11):1245-1251. doi: 10.1016/0895-4356(94)90129-5

15. Ogrinc G, Mooney SE, Estrada C, et al. The SQUIRE (Standards for QUality Improvement Reporting Excellence) guidelines for quality improvement reporting: explanation and elaboration. Qual Saf Health Care. 2008;17 Suppl 1 (Suppl_1):i13-i32. doi: $10.1136 /$ qshc.2008.029058 
16. Verma SP, Mahboubi H. The changing landscape of total laryngectomy surgery. Otolaryngl Head Neck Surg. 2014;150(3):413-418. doi: $10.1177 / 0194599813514515$

17. Withrow KP, Rosenthal EL, Gourin CG, et al. Free tissue transfer to manage salvage laryngectomy defects after organ preservation failure. Laryngoscope. 2007;117(5):781-784. doi: 10.1097/MLG.0b013e3180332e39
18. Spiegel JH, Polat JK. Microvascular flap reconstruction by otolaryngologists: prevalence, postoperative care, and monitoring techniques. Laryngoscope. 2007;117(3):485-490. doi: 10.1097/MLG.0b013e31802d6e66

19. Goepfert RP, Hutcheson KA, Lewin JS, et al. Complications, hospital length of stay, and readmission after total laryngectomy. Cancer. 2017;123(10):1760-1767. doi: 10.1002/cncr.30483

This article meets the Accreditation Council for Graduate Medical Education and the American Board of Medical Specialties Maintenance of Certification competencies for Patient Care, Medical Knowledge, Systems-Based Practice, and Practice-Based Learning and Improvement.

(C2021 by the author(s); licensee Ochsner Journal, Ochsner Clinic Foundation, New Orleans, LA. This article is an open (c) (i) access article distributed under the terms and conditions of the Creative Commons Attribution (CC BY) license (creativecommons.org/licenses/by/4.0/legalcode) that permits unrestricted use, distribution, and reproduction in any medium, provided the original author(s) and source are credited. 